\title{
Ověření účinnosti nového hudebně-pohybového programu pro stř̌ední školy
}

\section{Effectivity verification of a new dance program for high schools}

\author{
Michaela Brtníková, Viléma Novotná, Martina Voříšková \\ Fakulta tělesné výchovy a sportu Univerzity Karlovy v Praze
}

\begin{abstract}
ABSTRAKT
$Z$ di̊vodu klesajícího zájmu středoškolských dívek o jakoukoli pohybovou aktivitu byl vytvořen hudebněpohybový program jako specifický podnět pro pohybovou činnost. Nový intervenční program odpovídá aktuálním zájmům a potřebám mladé generace, je založený na současných odborných poznatcích o hudebně-pohybové výchově (HPV) v zahraničí. Je prezentován v podobě třídilné sady DVD s ukázkami tanečních stylů a metodickým návodem. Pro zjištění efektivity programu byl realizován experiment, jehož záměrem bylo porovnat úroveň ovlivnění hudebně pohybových dovedností. Experiment byl vyhodnocen čtyřfaktorovou analýzou kovariance $3 \times 2 \times 2 \times 2$ s pevnými efekty (intervence $x$ mimoškolní aktivita $x$ věk $x$ učitel) a kovariační promènnou (pretest). Zjištěné výsledky velkou měrou přispěly $k$ rozšiřrení poznatků a zkušeností o procesu vzdělávání v HPV. Využití DVD s novým hudebně-pohybovým programem, založeným na uvědomèlém osvojování moderních tanečních forem, mělo signifikantní vliv na rozvoj hudebních i pohybových dovedností měřených osob. Úroveň rytmických schopností se výrazně odlišovala podle věku, proto je třeba vytvářet programy s priměřenou obtížností rytmických cvičení. V našem př́padě se tanečni schopnosti projevily jako třídimenzionální s latentními společnými faktory - rytmickým, pamětovým a pohybovým. Objevil se i trend upřednostňovat ve výuce tanečně-pohybové dovednosti před rozvijením tanečně-hudebních schopností. Tím vzniká domněnka, že taneční zájmová činnost klade velký dưraz na osvojování specifických pohybových dovedností (taneční techniku), zanedbává však základy vnímání hudby a rytmickou percepci, ze kterých by měly tanečně-pohybové predpoklady vycházet. Bylo prokázáno, že taneční schopnosti lze efektivně rozvijet již krátkodobým cíleným pohybovým programem v rámci školni TV. Výsledky rovněž poukázaly na neefektivnost a nedostatečnost současné školní i mimoškolní hudebněpohybové výchovy. Pojetí zkoumání problému přispělo k obohacení vědecko-výzkumných poznatků oblasti taneční teorie a zejména poznatkư o faktorové struktuře tanečních schopností. Uvedené hypotézy jsou však ve stádiu pilotního zjištèní a k prokázání jejich vědecké významnosti je třeba realizovat nový výzkum, patřičně specializovaný.
\end{abstract}

\footnotetext{
ABSTRACT

Due to decreasing interest of adolescent girls in any physical activity, a new dance program was created on three DVDs with samples of different dance styles and directions how to teach them. The program follows the interest of the teenage generation and is based on modern methods from abroad. An experiement was conducted to verify the efficiency of the new dance program. The aim of the experiment was to compare the level of dance skills improvement. 4-way ANCOVA was used to evaluate the experiment. The covariates were dance program, afterschool activities, age, teacher, pre-test performance.

The results of the research enriched the field of dance education, especially the process of learning new dance skills. The new dance program improved the results of all music and motor skills and from the view point of development of specific dance skills it was considered very efficient. The level of music skills varied according to the age of research subjects, which shows the importance of creating programs with adequate contents according to the students age.

Our research showed the dance skills as three-dimensional with three latent factors: rhythmic, memory and motor. The results also pointed out the fact that after school activities focus on improvement of dance motor skills (dance technique) but neglect the music and rhythmic perception, which is the initiator of dance movement.
} 
Our results also confirmed that dance skills can be improved by a short term dance program within the school P.E. lessons. The results of the research also showed unsignificant effectivity of recent dance motor programs at schools in development of dance skills. The results contributed to the scientific field of dance education, especially the factor structure of dance skills. All the results were formulated from a pilot study and need to be confirmed by additional research.

Kličová slova: $\quad$ hudebnè-pohybová výchova, taneční dovednosti, taneční program, moderní taneční styly, experiment

KEY WORDS: $\quad$ dance education, dance skills, dance program, modern dance styles, experiment

\section{ÚVOD}

Současná doba se vyznačuje poklesem objemu pohybové aktivity v existenci novodobé společnosti. Aktivní životní styl ustupuje zájmům nových technologií a mezi lidmi stoupá výskyt onemocnění, která mají často původ ve snižování podílu pohybu v životě člověka.

Současní odborníci a vědci se zaměřují na možnosti řešení kritické situace pohybové pasivity, od teoretických základů vzniku a řešení problému, až po vytváření nabídky nových pohybových programů, které by měly splňovat požadavky a očekávání současné společnosti, a zároveň účinně ovlivňovat nárůst pohybové aktivnosti v životě člověka (Butler \& Anderson, 2002, Bernard et al., 2007). Vědci se shodují, že klíčovým obdobím pro vytvoření kladného vztahu k pohybové aktivitě je mládí (Cavill, Biddle, \& Sallis, 2001; Riddoch, 1998). Účast v běžné fyzické aktivitě je spojena s pozitivními výstupy, na nichž závisí další aktivní pohybová činnost (Strong et al., 2005). Abychom dosáhli pozitivních prožitků u mladých účastníků pohybové aktivity, musíme nabízet moderní aktuální atraktivní pohybové činnosti, které však mají kladný ověřený vliv na rozvoj pohybových schopností a pozitivní ovlivňování osobnosti člověka. Některé současné pohybové programy dokonce demotivují mládež z důvodu zastaralé formy či způsobu jejich prezentace. Ernst, Pangrazi \& Corbin (1998) konstatují, že tradiční pohybové programy se až př́liš zaměřují na rozvoj fyzické zdatnosti a opomíjí základní cíl, motivaci cvičenců $\mathrm{k}$ další pohybové aktivitě. Je proto potřeba jít $s$ dobou ve smyslu modernizace náplně nabízené pohybové aktivity k dosažení stanovených cílů výuky.

Jednou ze současných oblíbených pohybových činností je tanec. Většina lidí si jej spojuje spíše se zábavou než s tělesným cvičením, a proto je potřeba popularitu tance využít ke zvyšování celkového objemu pohybu v rámci způsobu života, zejména mládeže. Současná hudebně-pohybová výchova (HPV) však velmi často využívá starší, tradiční formy výuky a setkává se s klesajícím zájmem studentů (Frömel et al. 2002). V duchu modernizace HPV je potřeba studentům nabídnout výuku prostřednictvím moderních tanečních stylů, které obdivují a které je podněcují a motivují se jich aktivně účastnit. Přidáme-li modernizaci výukových metod, zvyšujeme-li podíl podnětů pro vlastní kreativitu a spolupráci studentů při tvorbě a realizaci taneční činnosti, zvyšujeme tím motivaci k budoucí pohybové aktivitě.

Většina odborníků se shoduje, že v období adolescence pohybová aktivita prudce klesá (Sallis, 2000). Tento pokles je ještě výraznější u adolescentních dívek, které se snaží vyhýbat povinným formám pohybových činností všemi zpo̊soby (Caspersen, Pereira, \& Curran, 2000). Právě tanec je jednou z mála pohybových aktivit, které jsou zejména mezi dívkami ve věku adolescence velmi populární. Proto je třeba zavádět moderní formy tanečních aktivit do hudebně pohybové výchovy a dívky podněcovat $\mathrm{k}$ pohybu formou oblíbené činnosti.

Modernizace hudebně-pohybové výchovy se stala základním cílem naší práce. Projekt byl zaměřen na skupinu dívek ve věku adolescence v rámci povinné školní tělesné výchovy právě proto, že škola je klíčovou institucí pro zprostředkování a propagaci pohybové aktivity mezi adolescenty (Wechsler, Devereaux, Davis, \& Collins, 2000). Základem projektu bylo vytvoření třídílné sady DVD s výukovým hudebně-pohybovým programem, který byl vytvořen na základě současných trendů v pohybovém projevu, poznatků a videomateriálů ze špičkových vzdělávacích tanečních institucí v USA a Dánsku. Obsahuje ukázky moderních tanečních stylů, základní poznatky z teorie tance, širokou nabídku činností pro roz- 
voj taneční techniky, metodiku nácviku různých tanečních stylů a tvorbu pohybových skladeb. Třídílná sada DVD je prezentována na emailové adrese: dvd.tanec@gmail.com.

Záměrem projektu bylo vědecko-výzkumnými metodami ověřit efektivitu nově vytvořeného hudebně-pohybového programu a srovnat ji s efektivitou tradičně vyučované hudebně-pohybové výchovy.

Projekt byl financován Grantovou agenturou Univerzity Karlovy v Praze v roce 2009 (projekt č. 70009). Řešení proběhlo v návaznosti na úkol výzkumného záměru UK v Praze, FTVS, MSM 0021620864. Tento výstup rovněž vznikl v rámci projektu Specifického vysokoškolského výzkumu 2010-261601.

\section{POSTUP A METODY VÝZKUMU}

Byl sledován vliv krátkodobé intervence tanečního programu ve školní tělesné výchově na vybrané testy hudebně-pohybových dovedností. Pro přiblížení zmíněnému kauzálnímu vztahu byla použita experimentální metoda empirického výzkumu (Blahuš, 1996). Jednalo se o longitudinální sledování intraskupinových a interskupinových vztahů mezi vstupní proměnnou v podobě aplikace tanečního programu a výstupní proměnnou, kterou tvořily výsledky hudebně-pohybových testů.

Z hlediska nově vytvořeného tanečního programu se jednalo o heuristický experiment. Celý projekt byl realizován ve školním prostředí. Vzhledem k záměrnému výběru skupin měřených osob (školních tř́íd) se jednalo o kvaziexperimentální plán studie (Thomas \& Nelson, 1996). Vyhodnocení studie, ve které nedošlo ke zcela randomizovanému výběru osob do skupin, bylo velice problematické, protože nebylo možno zaručit, zda rozdíly ve výsledcích měření byly způsobeny naší intervencí nebo známými či neznámými rozdíly mezi skupinami. Byly proto porovnány vstupní hodnoty všech sledovaných skupin (pretest) a zjištěny rozdíly mnohem menší než diagnostická chyba měření (podrobněji v kapitole Statistické zpracování výsledků).

K vyhodnocení výsledků byla použita analýza kovariance sloužící k odstranění vlivů rušivých proměnných v nerandomizovaných studiích (Delaney \& Maxwell, 1981). Základní myšlenkou kovariační analýzy bylo rozšíření, nebo též modifikace modelu analýzy rozptylu s jedním nebo více kategoriálními faktory na model obsahující kontrolované proměnné (kvantitativní spojité), mající rovněž vliv na hodnoty vysvětlovaných proměnných (Hebák, Hustopecký \& Malá, 2005). Rušivé proměnné byly zahrnuty do výzkumného plánu v podobě kovariačních proměnných.

$\mathrm{V}$ našem výzkumu byly uvedeny proměnné, které by mohly ovlivnit výsledný efekt: věk, školní a mimoškolní hudební či pohybová výchova, osobnost učitele, hodnoty pretestu, zdravotní stav, rodinná výchova a postoje rodičů $\mathrm{k}$ tělesným aktivitám, spontánní aktivity dívek. Na základě výsledků některých výzkumů (Kodým, Blahuš \& Hříbková, 1987) byla z rušivých proměnných vyloučena rodinná výchova, protože měla na výkon malý, respektive nevýznamný vliv. Zdravotní stav byl posouzen na základě účasti dívek v hodině tělesné výchovy. Dívky, které se aktivně neúčastnily hodin TV v $83 \%$ z celkové délky programu (maximální absence dvě vyučovací hodiny), byly ze závěrečné analýzy vyřazeny. Vliv spontánních aktivit dívek byl minimalizován časovým výběrem realizace intervenčního programu do období před uzavřením známek ke konci školního roku. Ostatní spontánní aktivity dívek, stejně jako mimoškolní hudební a pohybové aktivity, byly zjištovány formou řízeného rozhovoru. Výsledky byly zaneseny do výsledné analýzy jako kategorická proměnná (faktor). Další kategorickou proměnnou byl věk měřených osob a osobnost učitele. Hodnoty pretestu byly zaneseny jako kovariační proměnné.

Délka cíleného hudebně-pohybového programu byla zvolena na základě Rámcových vzdělávacích programů České republiky a pravidel tvorby programů pro tělesnou výchovu na šest týdnů. Z hlediska efektivity a obsahu aktivit $\mathrm{v}$ TV bylo vhodné měnit styl pohybových aktivit po jednom až dvou měsících výuky (Ravn, 2007).

\section{VÝZKUMNÝ SOUBOR A OBSAH POHYBOVÉHO PROGRAMU}

Do výběru byly zahrnuty studentky dvou různých gymnázií: Gymnázia Elgartova v Brně a Gymnázia Christiana Dopplera v Praze. Šestitýdenního programu se zúčastnilo vždy šest tř́íd vyššího stupně gymnázia (dívky ve věku 15 až 19 let), celkem tedy 201 dívka. Z šesti tříd (skupin) byly zcela náhodně vytvořeny dvě experimentální skupiny (E), dvě kontrolní skupiny K0 a dvě kontrolní skupiny K1. Skupiny K1 
se po dobu šesti týdnů věnovaly programu hudebně-pohybové výchovy vytvořenému jejich učitelem. Experimentální skupiny se věnovaly novému hudebně-pohybovému programu, který byl vytvořen stejným učitelem po nastudování tř́dílné sady DVD. Kontrolní skupiny K0 se po celou dobu šesti týdnů nevěnovaly žádnému typu hudebně-pohybové výchovy.

Každá hodina tělesné výchovy probíhala zcela podle rozhodnutí vyučujícího na základě stručných poznámek $\mathrm{k}$ přípravě na hodinu. Všechny př́pravy byly zhotoveny ještě před započetím experimentu. $\mathrm{V}$ jeho průběhu byly pozměněny jen minimálně vzhledem $\mathrm{k}$ potřebám skupiny, což vyplývá z pravidel pro tvorbu hudebně-pohybových programů (Ravn, 2007).

\section{STATISTICKÉ ZPRACOVÁNÍ VÝSLEDKŮ}

K vyhodnocení výsledků jsme využili čtyřfaktorovou 3x2x2x2 analýzu kovariance (ANCOVA) s pevnými efekty (intervence $\mathrm{x}$ mimoškolní aktivita $\mathrm{x}$ věk $\mathrm{x}$ učitel) a kovariační proměnnou (pretest). Zpracování výsledků bylo realizováno statistickým programem SPSS.

Mimoškolní aktivity (včetně hudební či pohybové výchovy) byly analyzovány na základě řízeného rozhovoru. Rozhovory proběhly s dívkami a jejich učiteli před koncem hudebně-pohybového programu. Pro naše potřeby jsme mimoškolní aktivity (MA) rozdělili na hudební (hodina hudební výchovy či lekce hraní na hudební nástroj), pohybové (aktivity vyžadující uplatnění rovnováhových či koordinačních schopností) a taneční (gymnastika či tanec). Stejný jedinec mohl být zařazen do několika skupin. Práh pro zařazení do některé ze skupin MA byl alespoň 60 minut týdně. Do závěrečné analýzy byly MA uvedeny jako faktor se dvěma hladinami (prováděl - neprováděl).

Vzhledem k vysokému předpokladu korelace pretestových hodnot s posttestovými byly pretestové hodnoty zahrnuty do závěrečného zpracování dat jako kovariační proměnná. Protože rozvoj zejména koordinačních schopností, jež se uplatňují ve všech vybraných testech, je závislý na věku, byl i věk zadán jako faktor.

Základními předpoklady analýzy kovariance jsou normální rozložení závislé proměnné a homoskedasticita (Hebák, Hustopecký \& Malá, 2005). Pro testování homogenity vnitroskupinových rozptylů byl použit Levenův test, kde byl zjištován rozptyl každé závisle proměnné na základě absolutních odchylek hodnot od príslušné střední hodnoty dané skupiny. Hladina k zamítnutí nulové hypotézy byla vzhledem $\mathrm{k}$ přesnosti získaných dat zvolena na 0,05 .

Dalším předpokladem pro úspěšné využití ANCOVY je lineární závislost kovariačních proměnných na vysvětlované proměnné a shoda regresních koeficientů ve všech skupinách. Ještě před započetím statistických procedur bylo graficky i početně zjištěno, že regresní prrímky se ve sledované oblasti věku neprotínají. Tím jsme mohli zamítnout hypotézu o interakci kovariačních proměnných a faktorů.

Pro posouzení věcné významnosti tzv. "size of effect" byla použita druhá mocnina koeficientu $\eta$, který vysvětluje procento vysvětleného rozptylu, nezávislé na statistické významnosti (Blahuš, 2000). Statistická významnost byla $\mathrm{v}$ našem př́padě logicky bezpředmětná $\mathrm{z}$ důvodu nerandomizovaného rozdělení testovaných osob do skupin.

\section{VÝSLEDKY}

$\mathrm{Z}$ důvodu nerandomizovaného rozdělení testovaných osob do př́ílušných skupin byly porovnány pretestové výsledky všech indikátorů. S přihlédnutím na hodnoty specifické reliability a střední chyby měření jednotlivých indikátorů bylo možné konstatovat, že průměrné hodnoty, směrodatné odchylky a rozptyly se nelišily. Na základě tohoto zjištění lze poukázat na stejné vlastnosti randomizovaného výběru a použít analýzu kovariance, jejímž základním pravidlem je randomizace výběru osob do skupin.

Faktor učitele se jevil jako nadbytečný, protože neovlivňoval velikost efektu ve všech interakcích v jednotlivých testech ani v hlavním efektu. Zároveň větší počet faktorů snižoval sílu předpokladu o homogenitě rozptylu závisle proměnné $\mathrm{v}$ jednotlivých skupinách. Přistoupili jsme tedy k modelu ANCOVA $3 \times 2 \times 2 \mathrm{~s}$ faktory intervence $\mathrm{x}$ mimoškolní aktivita $\mathrm{x}$ věk a jednou kovariační proměnnou. Vliv učitele byl rovněž vyloučen pomocí metody shody a rozdílu. Z porovnání výsledků na obou školách bylo zřejmé zlepšení experimentální skupiny, zatímco skupiny KO i K1 se významně nezlepšily. 
Výsledky výzkumu potvrdily poznatky z praxe HPV, že taneční schopnosti lze efektivně rozvíjet již krátkodobým cíleným hudebně-pohybovým programem $\mathrm{v}$ rámci školní tělesné výchovy. $\mathrm{Z}$ porovnání průměrných hodnot z pretestu a posttestu v jednotlivých skupinách (grafy 1 ) je zřejmé významné zlepšení experimentální skupiny. Naopak skupina K1, která se po stejnou dobu jako skupina E věnovala hudebně-pohybovým činnostem, se v rytmické percepci významně nezlepšila a dosáhla podobných hodnot jako kontrolní skupina K0.

Grafy 1 - Porovnání meziskupinových průměrů výsledků jednotlivých testů.

\section{Skupina E}
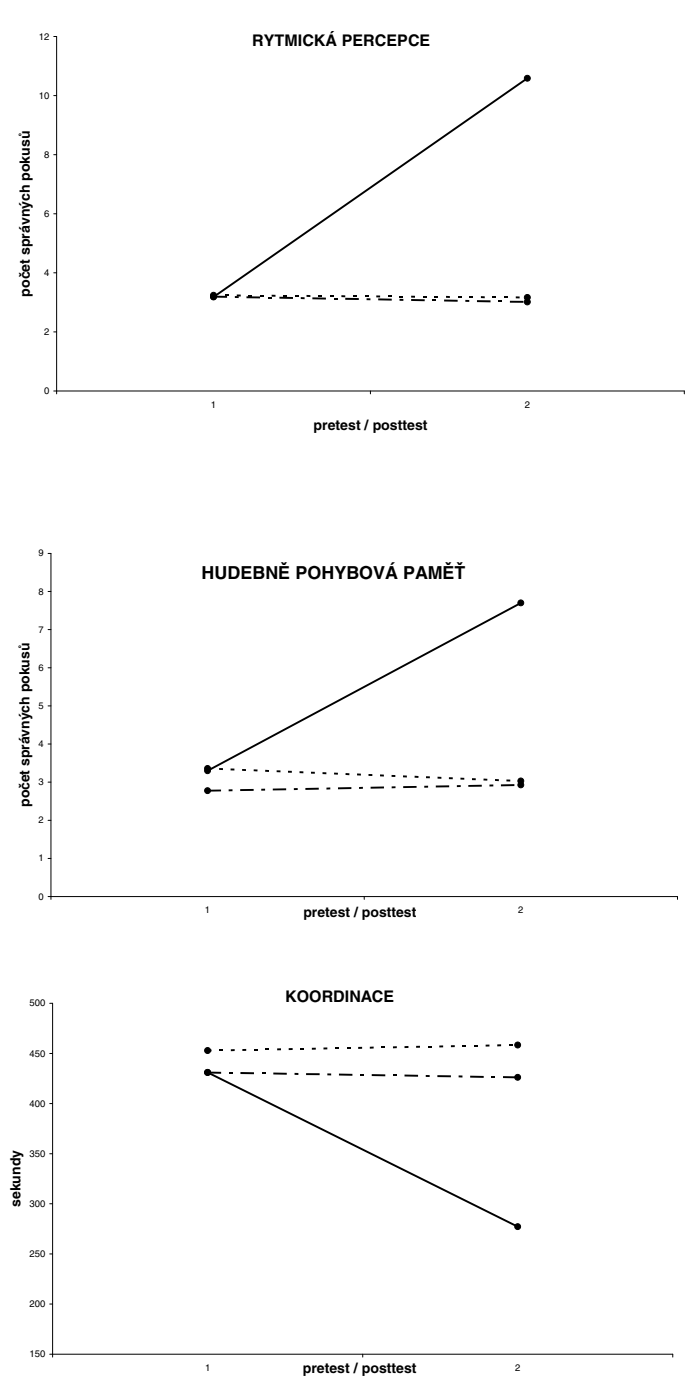

\section{Skupina K0 _........ Skupina K1}
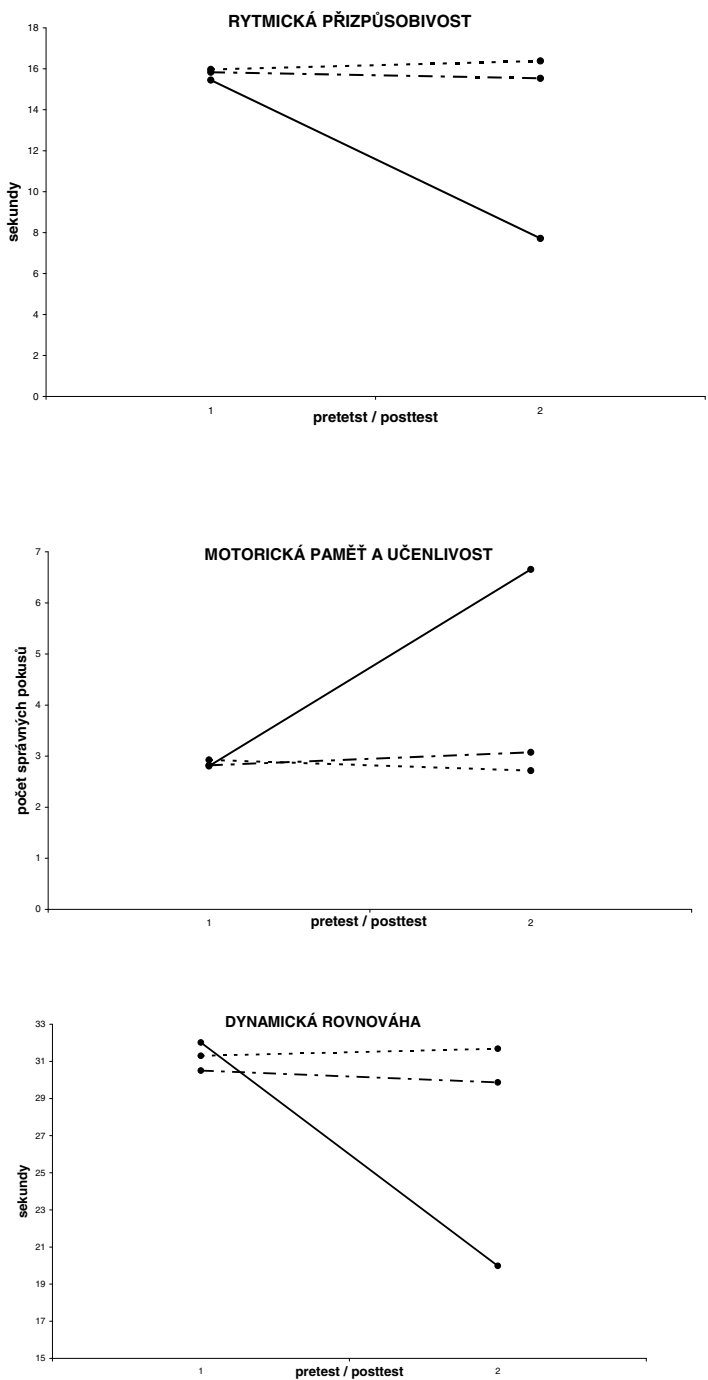

Z pretestového měření všech 201 osob je zřejmá stejná faktorová struktura jako při pilotním ověřování baterie testů. Porovnali jsme korelační matici výsledků z pretestu s korelační maticí výsledků posttestu: byla zřetelná změna ve vzájemných korelacích testů rytmických, pohybových a pamětových na hladině $2, \mathrm{tj}$. $\mathrm{v}$ experimentální skupině. Došlo dokonce i ke změně faktorové struktury, zejména testu HPP a MP (viz tab. 1 a 2). 
Tabulka 1 - Změna faktorové validity pretestu a posttestu skupiny E. Koeficienty faktorové validity jednotlivých indikátorů.

\begin{tabular}{|c|c|c|c|c|c|}
\hline \multicolumn{3}{|c|}{ PRETEST } & \multicolumn{3}{|c|}{ POSTTEST } \\
\hline & $\begin{array}{c}\text { TANEČNĚ } \\
\text { POHYBOVÁ } \\
\text { SCHOPNOST }\end{array}$ & $\begin{array}{c}\text { TANEČNĚ } \\
\text { HUDEBNÍ } \\
\text { SCHOPNOST }\end{array}$ & & $\begin{array}{c}\text { TANEČNĚ } \\
\text { POHYBOVÁ } \\
\text { SCHOPNOST }\end{array}$ & $\begin{array}{c}\text { TANEČNĚ } \\
\text { HUDEBNÍ } \\
\text { SCHOPNOST }\end{array}$ \\
\hline $\mathrm{pRP}$ & 0.09 & 0.80 & $\mathrm{RP}$ & 0.05 & 0.85 \\
\hline pPRI & -0.06 & 0.94 & PRI & -0.10 & 0.87 \\
\hline pHPP & -0.01 & 0.87 & HPP & 0.69 & -0.04 \\
\hline pMP & 0.91 & -0.04 & MP & 1.05 & -0.27 \\
\hline pKOO & 0.93 & 0.02 & KOO & 0.51 & 0.31 \\
\hline $\mathrm{pDR}$ & 0.87 & 0.03 & $\mathrm{DR}$ & 0.44 & 0.28 \\
\hline
\end{tabular}

Faktorová validita byla zjištěna exploratorním přístupem v programu SPSS, metodou nejmenších čtverců, rotací Direct Oblimin.

Tabulka 2 - Náznak tř́ídimenzionální struktury tanečních schopností. Koeficienty faktorové validity jednotlivých indikátorů.

\begin{tabular}{|c|c|c|c|}
\hline & $\begin{array}{c}\text { TANEČNĚ } \\
\text { POHYBOVÁ } \\
\text { SCHOPNOST }\end{array}$ & $\begin{array}{c}\text { TANEČNĚ } \\
\text { HUDEBNÍ } \\
\text { SCHOPNOST }\end{array}$ & $\begin{array}{c}\text { PAMĚŤOVÁ } \\
\text { SCHOPNOST }\end{array}$ \\
\hline RP & 0.05 & 0.82 & 0.08 \\
\hline PRI & 0.01 & 0.89 & -0.07 \\
\hline HPP & -0.14 & 0.12 & 1.00 \\
\hline MP & 0.19 & -0.12 & 0.75 \\
\hline KOO & 0.96 & 0.04 & 0.03 \\
\hline DR & 0.83 & 0.02 & -0.02 \\
\hline
\end{tabular}

Pozn.: Použití tř̌́ latentních společných faktorů je pouze orientační a slouží k zamyšlení nad faktorovou strukturou tanečních schopností, protože není splněno základní pravidlo minimálního počtu tří indikátorů pro jeden latentní společný faktor.

Faktorová validita byla zjištěna exploratorním přístupem v programu SPSS, metodou nejmenších čtverců, rotací Direct Oblimin.

Semikvalitativně hodnocené testy improvizace i společné tvořivosti demonstrovaly rovněž signifikantní zlepšení v tanečních dovednostech u experimentální skupiny E. Naopak kontrolní skupiny K0 i K1 se v hodnocení pretestu i posttestu významně nelišily.

Z hlediska mimoškolních pohybových aktivit se nadbytečnou stala kategorie pohybových aktivit, protože testované dívky nedělaly mimo školu žádnou pohybovou aktivitu spojenou s využitím rovnováhových či koordinačních schopností jinou než tanec. Tabulka 3 uvádí výsledky dívek s mimoškolní hudební (HV) či taneční (HPV) aktivitou srovnané s výsledky dívek, jež se žádné prríbuzné aktivitě ve volném čase nevěnovaly. Jsou zde výrazné rozdíly tančících a hudebně aktivních dívek. Přestože základem tance je správné vnímání rytmu a jeho přizpůsobení, je zřejmé, že tancující dívky dosáhly podobných hodnot (průměrná $\mathrm{RP}=2,80, \mathrm{PRI}=15,37, \mathrm{HPP}=3,07$ ) jako dívky, které se tanci mimo školu nevěnovaly (průměrná $\mathrm{RP}=2,11, \mathrm{PRI}=18,08, \mathrm{HPP}=2,42$ ). Výsledky testu motorické paměti a učenlivosti se mezi různými skupinami nelišily. 
Tabulka 3 - Srovnání výsledků pretestových výkonů na základě druhu mimoškolních aktivit.

\begin{tabular}{|c|c|c|c|c|c|c|c|c|}
\hline & \multicolumn{2}{|c|}{ pouze HV } & \multicolumn{2}{|c|}{ pouze HPV } & \multicolumn{2}{|c|}{ žádná MA } & \multirow{2}{*}{$\begin{array}{l}\text { stř. chyba } \\
\text { měření }\end{array}$} & \multirow{2}{*}{$\begin{array}{l}\text { kritický } \\
\text { rozdíl } \\
\text { výkonů }\end{array}$} \\
\hline & $\mathrm{N}$ & průměr & $\mathrm{N}$ & průměr & $\mathrm{N}$ & průměr & & \\
\hline $\mathrm{pRP}$ & 24 & 6.33 & 30 & 2.80 & 131 & 2.11 & 0.78 & 2.18 \\
\hline pPRI & 24 & 9.21 & 30 & 15.37 & 131 & 18.08 & 1.51 & 4.23 \\
\hline pHPP & 24 & 5.08 & 30 & 3.07 & 131 & 2.42 & 0.72 & 2.02 \\
\hline pMP & 24 & 3.21 & 30 & 3.87 & 131 & 2.31 & 0.61 & 1.71 \\
\hline pKOO & 24 & 409.04 & 30 & 300.47 & 131 & 499.95 & 26.73 & 74.84 \\
\hline $\mathrm{pDR}$ & 24 & 30.38 & 30 & 22.07 & 131 & 34.69 & 2.33 & 6.52 \\
\hline
\end{tabular}

Z důvodu nerandomizovaného rozdělení sledovaných osob do skupin byly výsledky formulovány pomocí $\eta 2$ (tzv. size of effect), posouzením věcné významnosti.

Analýza kovariance pro test rytmické percepce potvrdila velký vliv hladiny hudebně-pohybového programu (hladina 0 pro skupinu K0, hladina 1 pro skupinu K1 a hladina 2 pro skupinu E) na výsledný efekt. Z grafů 1 je rovněž zřejmý zejména vliv intervenčního programu experimentální skupiny, zatímco výsledky skupin K0 a K1 se od sebe významně nelišily.

Velice významný byl věk, který nejvíce ovlivnil výsledky pretestu. Z hudební psychologie vyplynula zřejmá závislost rozvoje hudebních schopností na věku (zejména rytmických), což potvrdily i výsledky ANCOVY rytmické percepce $(\eta 2=0,61)$. Protože u skupin K0 a K1 nedošlo k významnému zlepšení mezi pretestem a posttestem, vliv věku byl nesporný i na výsledný efekt. Při porovnání korelace věku $\mathrm{s}$ výsledky pretestu a posttestu u skupiny $\mathrm{E}$, byl patrný vliv věku pouze na pretestové hodnoty (počáteční úroveň tanečních schopností).

ANCOVA rytmické přizpůsobivosti přinesla podobné výsledky jako rytmická percepce. Vliv věku a hladiny intervenčního programu byl největší. Věk totiž koreloval nejvíce s rytmickou přizpůsobivostí $(\eta 2=0,99)$. Rovněž hudební psychologie upozorňuje na podstatný vliv věku na rytmické schopnosti dětí. Stejně jako u rytmické percepce $\mathrm{z}$ korelační matice věku u skupiny E byl zřejmý vliv pouze na pretestové výsledky. Samostatné hudební mimoškolní aktivity neměly vliv na významné zlepšení rytmické přizpůsobivosti dívek $(\eta 2=0,06)$. Podrobné výsledky jsou uvedeny v tabulce 4 .

Tabulka 4 - Výsledky analýzy kovariance pro rytmickou přizpůsobivost.

\begin{tabular}{|c|c|c|c|c|c|c|}
\hline \multicolumn{7}{|c|}{ TEST MEZISKUPINOVÝCH EFEKTU゚ } \\
\hline \multicolumn{7}{|c|}{ Závislá proměnná: rytmická přizpůsobivost } \\
\hline & $\begin{array}{l}\text { Typ součtu } \\
\text { čtverců III }\end{array}$ & $\begin{array}{c}\text { Stupně } \\
\text { volnosti }\end{array}$ & $\begin{array}{c}\text { Průměrné } \\
\text { čtverce }\end{array}$ & $\mathrm{F}$ & Sig. & $\eta 2$ \\
\hline Hranice & 116.77 & 1 & 116.77 & 16.94 & 0.01 & 0.79 \\
\hline PRETEST & 712.03 & 1 & 712.03 & 58.57 & 0.00 & 0.45 \\
\hline HLADINA & 783.86 & 2 & 391.93 & 2.68 & 0.46 & 0.88 \\
\hline VEK & 410.95 & 50 & 8.22 & 0.88 & 0.79 & 0.99 \\
\hline $\mathrm{HV}$ & 3.42 & 1 & 3.42 & 0.06 & 0.85 & 0.06 \\
\hline HLADINA * VEK & 603.55 & 53 & 11.39 & 1.09 & 0.64 & 0.98 \\
\hline HLADINA * HV & 52.96 & 1 & 52.96 & 4.89 & 0.16 & 0.71 \\
\hline $\mathrm{VEK}^{\star} \mathrm{HV}$ & 108.28 & 11 & 9.84 & 0.90 & 0.63 & 0.81 \\
\hline HLADINA * VEK ${ }^{\star} \mathrm{HV}$ & 21.65 & 2 & 10.83 & 0.89 & 0.41 & 0.02 \\
\hline
\end{tabular}

Hladina - hladina intervenčního programu

HV - mimoškolní hudební výchova

Sig. - statistická významnost (uvedena pouze orientačně) 
ANCOVA testu hudebně-pohybové paměti ukázala již menší vliv věku na výsledný efekt $(\eta 2=0,41)$. Největší vliv se projevil u společného působení hladiny intervenčního programu a věku $(\eta 2=1,0)$, následované samostatným působením hladiny intervenčního programu $(\eta 2=0,81)$.

ANCOVA testu motorické paměti a učenlivosti ukázala největší vliv hladiny intervenčního programu na její rozvoj $(\eta 2=0,86)$. V kombinaci s mimoškolními tanečními aktivitami měl nový taneční program rovněž velký vliv na výsledný efekt $(\eta 2=0,92)$. Vliv věku na rozvoj motorické paměti a učenlivosti byl mnohem menší než $\mathrm{v}$ př́ípadě rytmických schopností $(\eta 2=0,17)$.

ANCOVA testu koordinace ukázala velký vliv věku na koordinační schopnosti $(\eta 2=1,0)$. Potvrdila teorii sportovního tréninku v oblasti rozvoje koordinace $\mathrm{v}$ adolescentním věku. Vliv hudebně-pohybového programu byl rovněž výrazný a prokázal možnosti rozvoje koordinace krátkodobým působením tanečních aktivit $(\eta 2=0,95)$.

ANCOVA dynamické rovnováhy prokázala výrazný vliv mimoškolních tanečních aktivit na zlepšení dynamické rovnováhy $(\eta 2=1,0)$. Svůj vliv měl také věk, což je zřejmé rovněž z teorie sportovního tréninku v oblasti rozvoje rovnováhových schopností v adolescentním věku $(\eta 2=0,89)$.

\section{DISKUZE K VÝSLEDKŮM}

Naměřené výsledky potvrdily vyšší počáteční úroveň tanečních schopností u starších dívek, zřejmou již z teorie sportovního tréninku i hudební psychologie, pojednávající o nárůstu úrovně pohybových a hudebních schopností se stoupajícím věkem dětí. Výjimkou u pohybových schopností je pubertální věk, ale $\mathrm{v}$ př́ípadě našeho výzkumu se jednalo o postpubertální věk. Výrazný byl vliv věku na výsledky testu koordinace podporující teorii sportovního tréninku o rozvoji koordinačních schopností v souvislosti s věkem adolescentů.

Výsledky pretestu korelovaly s věkem mnohem více než posttestové výkony dívek experimentální skupiny. Byl tedy zřejmý vliv hudebně-pohybového programu na zlepšení výsledků měřených dívek v posttestu bez ohledu na věk.

Zajímavé rovněž bylo porovnání síly vlivu věku na jednotlivé testované dovednosti. $\mathrm{V}$ př́ípadě rytmických dovedností byl vliv věku největší. Úroveň rytmických schopností se tedy velmi významně odlišovala podle věku. K tomuto poznatku je třeba přihlédnout při tvorbě hudebně-pohybových programů, zejména při volbě obtížnosti rytmických cvičení.

Z porovnání výsledků kontrolní skupiny $(\mathrm{K} 0)$ a skupiny, která se věnovala běžnému hudebně-pohybovému programu, vytvořenému učitelem TV, se ukázala neefektivnost současné HPV. Potvrdilo to situaci HPV, která i přes svůj jedinečný výchovně-vzdělávací význam je v současné době v kritickém stavu z hlediska svého uplatňování v praxi. Předložená studie potvrdila odborné poznatky českých odborníků (např. Frömel, 2002) a dalších, konstatujících potřebu modernizace taneční výchovy v rámci TV ve školách v České republice. Vytvořený nový hudebně-pohybový program se současnou taneční tématikou efektivně zlepšil úroveň tanečních dovedností měřených kvantitativní škálou i taneční výkon hodnocený odborníky semi-kvalitativně.

Z výsledků vzájemných korelací indikátorů pretestu a posttestu byla zřejmá změna faktorové struktury tanečních schopností. Před vlastním experimentem se dívky zdokonalovaly v hudebních a pohybových dovednostech zvlášt' (např. v hudební výchově, ve hře na hudební nástroj; v gymnastice, př̀ mimoškolních tanečních aktivitách apod.). Dosahovaly proto různou úroveň tanečně-hudebního a tanečně-pohybového faktoru. Zatímco v obou kontrolních skupinách se korelační poměr významně nezměnil mezi pretestem a posttestem, v experimentální skupině došlo ke změně faktorové struktury. Taneční schopnosti se projevily jako tř́dimenzionální s latentními společnými faktory - rytmickým, pamětovým a pohybovým. Tato hypotéza však nemůže být podložena výsledky, protože není splněno pravidlo minimálního počtu tří indikátorů na jeden latentní společný faktor. Výsledky však mohou sloužit k novému zamyšlení nad faktorovou strukturou tanečních schopností a dát podnět $\mathrm{k}$ dalšímu vědeckému zkoumání.

Podnětem k zamyšlení je rovněž fakt, že většina tanečních kroužků (mimoškolní aktivity) se nevěnuje rozvoji tanečně-hudebních schopností a zaměřuje se pouze na tanečně-pohybové dovednosti, jak vyplývá $\mathrm{z}$ výsledků v tabulce 3 . Dívky, které ve volném čase navštěvovaly taneční kroužek, prokáza- 
ly stejnou úroveň základních rytmických schopností a hudebně-pohybové paměti jako dívky netančící. Naopak taneční dovednosti byly u tančících dívek v pretestu nadprůměrné. Dívky, které se věnovaly mimoškolním hudebním aktivitám, dosáhly nadprůměrných výsledků v pretestu tanečně-hudební schopnosti a nižší úrovně $\mathrm{v}$ tanečně-pohybové schopnosti. Intervencí novým hudebně-pohybovým programem došlo ke zlepšení obou složek tanečních schopností. Nízká počáteční korelace může být, vzhledem $\mathrm{k}$ výsledkům $\mathrm{v}$ tabulce 3 , způsobena př́lišnou specializací školních či mimoškolních aktivit v oblasti hudební a pohybové výchovy. Jedním $\mathrm{z}$ vysvětlení je možnost, že dívky věnující se hudební aktivitě (hře na hudební nástroj, zpěvu apod.) mají průměrně vyšší hodnoty tanečně-hudebních schopností než dívky věnující se tanci ( $v$ taneční skupině, $v$ gymnastice apod.). Tím však vzniká domněnka, že taneční zájmová činnost klade velký důraz na osvojování specifických pohybových dovedností (taneční techniku), zanedbává však základy vnímání hudby a rytmickou percepci, ze kterých by měly tanečně pohybové předpoklady vycházet. Uvedené hypotézy jsou však ve stádiu pilotního zjištění a k prokázání jejich vědecké významnosti je třeba realizovat nový výzkum, patřičně zaměřený.

\section{LITERATURA}

BERNARD, C. K., ANITA, W. P., JEROME, C. L., ELAINE, C. L. (2007). Daily step goal of 10,000 steps: A literature review. Clinical and Investigative Medicine, 30 (3), E146-E151. ISSN 0147-958.

BLAHUŠ, P. (2000). Statistická významnost proti vědecké průkaznosti výsledků výzkumu. Česká kinantropologie, 4 (2), 53-72. ISSN 1211-926.

BRTNÍKOVÁ, M., NOVOTNÁ, V., LESMERISES, L. (2009). Ověření reliability a validity nové baterie testů pro diagnostiku tanečních schopností. Česká Kinantropologie, roč. 13, č. 1, s. 50-59. ISSN 1211-9261. BUTTLER, L. F., \& ANDERSON, S. P. (2002). Inspiring Students to a Lifetime of Physical Activity. Journal of Physical Education, Recreation and Dance, 73 (9), 21-25. ISSN 0730-3084.

CASPERSEN, C. J., PEREIRA, M. A., \& CURRAN, K. M. (2000). Changes in physical activity in the United States, by sex and cross-sectional age. Medicine and Science in Sports and Exercise, 32(9), 16011609. ISSN 0195-9131.

CAVILL, N., BIDDLE, S., \& SALLIS, J. F (2001). Health enhancing physical activity for young people: Statement of the United Kingdom expert consensus conference. Pediatric Exercise Science, 13 (1), 12-25. ISSN 0899-8493

DELANEY, H. D., MAXWELL, S. E. (1981). On Using Analysis of Covariance in Repeated Measures Designs. Multivariate Behavioral Research, 16, 105-123. ISSN 0027-3171.

ERNST, M. P., PANGRAZI, R. P., \& CORBIN, C. B. (1998). Physical Education: Making a transition toward activity. Journal of Physical Education, Recreation and Dance, 69 (9), 29-32. ISSN 0730-3084.

FRÖMEL, K., STRATTON, G., VASENDOVA, J., PANGRAZI, R. P. (2002). Dance as a Fitness Activity. The Impact of Teaching Style and Dance Form. Journal of Physical Education, Recreation and Dance, 73 (5), 26-30.

HEBÁK, P., HUSTOPECKÝ, J., MALÁ, I. (2005). Vícerozměrné statistické metody (2). Praha: Informatorium. ISBN 80-7333-039-3.

KODÝM, M., BLAHUŠ, P., \& HǨÍBKOVÁ, L. (1987). K psychologii schopností a predikci senzomotorického výkonu. Praha: Academia. ISBN 21-097-87

RAVN, S. et al. (2007). Tidsskrift for Dans i Uddannelse. Tanec ve výchově. Gylling: Narayana Press. ISBN 92-893-1054-5.

RIDDOCH, C. (1998). Relationships between physical activity and physical health in young people. In S. Biddle, J. Sallis, \& N. Cavill (Eds.), Young and active? Young people and health-enhancing physical activity - evidence and implications (pp. 17-48). London: Health Education Authority. ISBN 0-7619-4498-2. SALLIS, J. F., PROCHASKA, J. J., \& TAYLOR, W. C. (2000). A review of correlates of physical activity of children and adolescents. Medicine and Science in Sports and Exercise, 32(5), 963-975. ISSN 0195-9131. STRONG, W. B., MALINA, R. M., BLIMKIE, C. J., DANIELS et al. (2005). Evidence based physical activity for school-age youth. Journal of Pediatrics, 146 (6), 732-737. ISSN 0022-3476. 
THOMAS, J. R., \& NELSON, J. K. (1996). Research methods in physical activity (3rd ed.). Champaign: Human Kinetics. ISBN 0-7360-4419-1.

WECHSLER, H., DEVEREAUX, R. S., DAVIS, M., \& COLLINS, J. (2000). Using the school environment to promote physical activity and healthy eating. Preventive Medicine, roč. 31, č. 2, s.121-137. ISSN 0749-3797. 